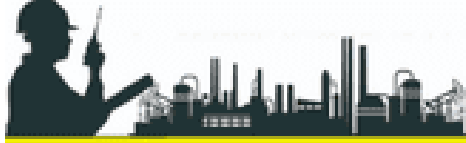

INVANTRI
Jurnal Penelititian tom

Inovasi Dan Pengelolaan Industri Years: Jurusan Teknik Industri $\mathbf{x x x x}$

\title{
ANALISIS PENGENDALIAN PERSEDIAAN BAHAN BAKU DI UKM BATIK SEKAR JATI STAR DENGAN MENGGUNAKAN METODE ABC ANALYSIS DAN ECONOMIC ORDER QUANTITY (EOQ)
}

\begin{abstract}
Fakhma Jiroyah(1)
Teknik Industri, Fakultas

Teknik, Universitas Hasyim

Asy'ari.

fakhmajiroyah@gmail.com

Sumarsono ${ }^{(2)}$

Teknik Industri, Fakultas

Teknik, Universitas Hasyim

Asy'ari.spasi

sonsumarsono13@gmail.com
\end{abstract}

\section{ABSTRACT}

SMEs of Batik "Sekar Jati Star" is one of the manufacturing industries engaged in batik making located in Jatipelem Village, Jombang and established since 1999. One of the typical motifs in ukm is jombangan motif that depicts the icon of Jombang city. The problem is management of raw material supplies is not optimal, where so far there is no evaluation and no inventory model method is used. So that the article aims to control the inventory of batik raw materials which include fabric, dye and wax. This inventory control includes the classification of each raw material for making batik using the ABC Analysis method. Next, determine the amount of economical raw material inventory using the Economic Order Quantity (EOQ) method. The results showed that the classification of raw materials using the $A B C$ analysis method shows that the raw materials included in category $A$ are fabric raw materials, category $B$ is dye raw materials, and category $C$ is wax raw materials. Implementation of the results of the classification of raw materials, so that the main priority of control is carried out according to the order of categories. The results of the EOQ inventory model show the monitoring of inventory control of raw materials for fabrics, dyes, wax for a year. Monitoring includes the time and quantity of economic $Q$, RoP, frequency of purchases, average inventory per week. Furthermore, from the comparison of inventory costs, the results of the EOQ model provide more economical results compared to the raw material inventory management that has been carried out so far for fabrics, dyes and waxes.

Keywords: SMEs of Jombang Batik, ABC Analysis, EOQ, Raw

Material Inventory

DOI : XXX-XXXX-XXXX 


\begin{abstract}
ABSTRAK
UKM Batik "Sekar Jati Star" merupakan salah satu industri manufaktur yang bergerak di bidang pembuatan batik yang terletak di Desa Jatipelem, Jombang dan berdiri sejak tahun 1999. Salah satu motif khas di UKM ini adalah motif Jombangan yang menggambarkan ikon kota Jombang. Permasalahan belum optimalnya pengelolaan persediaan bahan baku, dimana selama ini tanpa adanya evaluasi dan tidak menggunakan metode model persediaan.Sehingga artikel bertujuan melakukan pengendalian persediaan bahan baku batik yang meliputi kain, pewarna dan malam. Pengendalian persediaan meliputi klasifikasi setiap bahan baku pembuatan batik dengan metode ABC Analysis. Selanjutnya menentukan jumlah persediaan bahan baku yang ekonomis dengan metode Economic Order Quantity (EOQ). Hasil penelitian didapatkan hasil klasifikasi bahan baku dengan metode $\mathrm{ABC}$ analysis bahwa bahan baku yang termasuk dalam kategori A adalah bahan baku kain, kategori B adalah adalah bahan baku pewarna, dan kategori $C$ adalah bahan baku malam. Implementasi hasil klasifikasi bahan baku, bahwa agar prioritas utama pengendalian dilakukan sesuai urutan kategori. Hasil model persediaan EOQ, diketahui monitoring pengendalian persediaan bahan baku kain, pewarna, malam selama setahun. Monitoring meliputi waktu dan jumlah dari $Q$ ekonomis, RoP, frekuensi pembelian, rata-rata persediaan per minggu. Lebih lanjut dari hasil perbandingan biaya persediaan, didapatkan hasil model EOQ memberikan hasil lebih ekonomis dibandingkan pengelolaan persediaan bahan baku yang dilakukan selama ini untuk bahan kain, pewarna dan malam.
\end{abstract}

Kata Kunci:UKM Batik Jombang, ABC Analysis, EOQ, Persediaan Bahan Baku

\section{PENDAHULUAN}

Salah satu faktor keberhasilan suatu industri untuk mencapai tujuan adalah kemampuan dalam memenuhi permintaan pelanggan dan produk yang dihasilkan bisa memberikan kepuasan kepada pelanggan. Maka dari itu, suatu industri selalu berupaya untuk meningkatkan mutu produk yang dihasilkan, mengirimkan produk dengan waktu yang cepat, dan memberikan harga jual yang sesuai dengan kualitas sehingga suatu industri tetap mendapatkan permintaan dari pelanggan. Dari hal tersebut, dapat disimpulkan bahwa mutu, waktu dan harga merupakan faktor yang mempengaruhi keputusan permintaan pelanggan. Permintaan pelanggan yang tidak pasti mengakibatkan perusahaan perlu melakukan persediaan dengan baik. Persediaan sangat penting dalam kegiatan operasional perusahaan, sehingga membantu perusahaan untuk dapat selalu memenuhi permintaan pelanggan (Fogarty, et.al, 1991). Persediaan harus dimiliki setiap perusahaan sehingga perusahaan harus memiliki fasilitas untuk menyimpan persediaan tersebut yang biasa disebut gudang atau storage. Gudang merupakan tempat penyimpanan barang/bahan baku yang selanjutnya dilakukan proses manufaktur atau produksi menjadi finished product yang siap dipasarkan (Purnomo, 2004). Dalam hal pergudangan tidak hanya membahas tentang penyimpanan barang namun juga membahas tentang proses penangan barang dimulai dari penerimaan barang dari supplier hingga barang tersebut dikirimkan ke customer. Fungsi dan peran dari gudang memiliki dasar aktivitas pergudangan secara umum. Aktivias tersebut antara lain: Receiving, Prepackaging, Put Away, Storage, Oder picking, Packaging and/or picking, Sortation, Unitizing and Shipping (Frazelle, 2001). UKM Batik "Sekar Jati Star" merupakan salah satu industri manufaktur yang bergerak di bidang pembuatan batik yang terletak di Desa Jatipelem, Jombang dan sudah berdiri sejak tahun 1999. Salah satu motif khas di UKM ini adalah motif Jombangan yang menggambarkan ikon kota Jombang. Di UKM Batik "Sekar Jati 
Star" terdapat gudang yang merupakan tempat yang digunakan dalam proses produksi, penyimpanan dan pendistribusian bahan baku. Berdasarkan pengamatan awal terdapat permasalahan yang terjadi di gudang, permasalahan terasebut terkait dengan persediaan bahan baku sehingga dalam penyelesaiannya dibutuhkan suatu perencanaan pengendalian persediaanPengendalian persediaan ini meliputi klasifikasi setiap bahan baku pembuatan batik dengan metode ABC Analysis. Selanjutnya menentukan jumlah persediaan bahan baku yang ekonomis dengan metode EconomicOrderQuantity (EOQ). Tujuan EOQ adalah untuk mengetahui jumlah pemesanan yang akan dipesan ke supplier dengan biaya yang paling optimal. Peggunaan metode EOQ dapat mempertimbangkan adanya stok pengaman (safetystock) dan titik pemesanan kembali (reorderpoint), sehingga dengan adanya stok pengaman dan titik pemesanan kembali, maka apabila terjadi pemesanan mendadak gudang memiliki persediaan dan mengetahui kapan waktu untuk melakukan pemesanan kembali. Dengan menganalisis pengendalian bahan baku di UKM Batik "Sekar Jati Star", akan didapatkan hasil optimal terkait jumlah persediaan bahan baku dan biayanya. Lebih lanjut didapatkan hasil monitoring pengendalian persediaan bahan baku selama setahun untuk bahan baku kain, pewarna dan malam.

\section{METODE}

Metode penelitian yang dilakukan merupakan metode yang bersifat kuantitatif, dimana pada penelitian bersifat kuantitatif membutuhkan data-data yang jelas terkait penelitian. Penelitian kuantitatif disajikan dalam bentuk angka-angka maupun tabel-tabel.

Metode analisa data yang digunakan adalah metode $\mathrm{ABC}$ anlysis dan metode EOQ. Metode ABC Analysis merupakan metode pengklasifikasian barang berdasarkan peringkat nilai dari nilai tertinggi hingga terendah yang dibagi menjadi 3 kelompok yaitu kelompok A, B dan C.Metode ini sangat berguna dalam mengatur terhadap penentuan jenis barang yang paling penting dalam sistem persediaan (Rangkuti, 2004). Setiap masingmasing kelas memerlukan cara tersendiri untuk melakukan penanganan persediannya: (Markland, 1983).

Tabel 1. Penanganan Barang Menurut MasingMasing Kelas

\begin{tabular}{|c|c|c|c|}
\hline No & A & B & C \\
\hline 1 & $\begin{array}{c}\text { Pengendalian } \\
\text { persediaan ketat }\end{array}$ & $\begin{array}{c}\text { Pengendalian } \\
\text { persediaan } \\
\text { sedang }\end{array}$ & $\begin{array}{c}\text { Pengendalian } \\
\text { persediaan } \\
\text { longgar }\end{array}$ \\
\hline 2 & $\begin{array}{c}\text { Sistem } \\
\text { pencatatan } \\
\text { harus dipantau } \\
\text { sehingga tepat } \\
\text { dan akurat }\end{array}$ & $\begin{array}{c}\text { Sistem } \\
\text { pencatatan } \\
\text { harus baik }\end{array}$ & $\begin{array}{c}\text { Sistem } \\
\text { pencatatan } \\
\text { yang } \\
\text { sederhana }\end{array}$ \\
\hline 3 & $\begin{array}{c}\text { Peninjauan } \\
\text { secara tetap oleh } \\
\text { pengambil } \\
\text { keputusan }\end{array}$ & $\begin{array}{c}\text { Peninjauan } \\
\text { secara berkala }\end{array}$ & $\begin{array}{c}\text { Peninjauan } \\
\text { secara } \\
\text { sederhana }\end{array}$ \\
\hline
\end{tabular}

Economic Order Quantity (EOQ) merupakan jumlah barang yang diperoleh dengan biaya yang minimal atau dapat biasa dikatakan dengan jumlah pembelian yang optimal. Sehingga setiap kali melakukan pemesanan bahan baku,perusahaan dapat menghemat biaya yang akan dikeluarkan. Tujuan dari EOQ adalah menentukan jumlah persediaan dan biaya persediaan yang minimum sepanjang periode perencanaan produksi (Ardiprawiro, 2015). Perhitungan persediaan untuk metode EOQ menggunakan software POM QM for Windows

\section{HASIL DAN PEMBAHASAN}

Permintaan Batik di UKM Batik “Sekar Jati Star" Berikut adalah data permintaan bahan baku di UKM Batik “Sekar Jati Star" tahun 2o2o.

Tabel 2 Data Permintaan Bahan Baku Batik Tahun 2020

\begin{tabular}{|c|c|c|c|}
\hline \multirow{2}{*}{ Bulan } & \multicolumn{3}{|c|}{ Bahan Baku } \\
\cline { 2 - 4 } & Kain (meter) & Malam (gr) & Pewarna (gr) \\
\hline Januari & 510 & 10800 & 7500 \\
\hline Februari & 525 & 9200 & 6750 \\
\hline Maret & 615 & 9650 & 6800 \\
\hline April & 570 & 9100 & 6250 \\
\hline Mei & 585 & 9620 & 6300 \\
\hline Juni & 645 & 9500 & 7300 \\
\hline Juli & 680 & 10250 & 7150 \\
\hline Agustus & 590 & 10000 & 7100 \\
\hline September & 700 & 9800 & 6900 \\
\hline Oktober & 650 & 10550 & 7200 \\
\hline November & 575 & 10900 & 6725 \\
\hline Desember & 690 & 9150 & 7450 \\
\hline Total & 7335 & 118520 & 83425 \\
\hline Rata-rata & 611.25 & 9876.67 & 6952.08 \\
\hline
\end{tabular}


Berdasarkan tabel 1 diketahui bahwa rata-rata permintaan kain setiap bulan sebanyak 611 meter, rata-rata permintaan malam setiap bulan sebanyak 9876 gram atau 10 kilogram, dan rata-rata permintaan pewarna setiap bulan sebanyak 6952 gram atau 8 kilogram.

\section{Kuantitas Pemesanan ke Supplier}

UKM Batik "Sekar Jati Star" melakukan pemesanan ke supplier di daerah Solo dan Malang. Tingkat pemesanan bahan baku di UKM Batik "Sekar Jati Star" tidak menentu tergantung dari estimasi permintaan outlet dan ketersediaan bahan baku di gudang, sehingga bahan baku bisa mengalami stouckout maupun overstock yang menyebabkan waste stock (stok sampah/sudah rusak). Selain itu frekuensi pemesanan dapat mempengaruhi biaya pemesanan.

Tabel 3 Data Pemesanan Bahan Baku Batik

\begin{tabular}{|c|c|c|c|c|}
\hline No & Bahan Baku & Harga/satuan & Kebutuhan & Pembelian \\
\hline 1 & Kain & Rp. $1.170 .000,00$ & 82 roll & 82 roll \\
\hline 2 & Malam & Rp. $40.000,00$ & $119 \mathrm{~kg}$ & $125 \mathrm{~kg}$ \\
\hline 3 & Pewarna & Rp. $150.000,00$ & $84 \mathrm{~kg}$ & $90 \mathrm{~kg}$ \\
\hline
\end{tabular}

(Sumber: UKM Batik “Sekar Jati Star")

Diketahui bahwa satuan kain untuk pembelian ke supplier adalah roll. Dimana 1 roll sama dengan 90 meter. Dari tabel di atas, dapat diketahui bahwa kebutuhan bahan baku selama 1 tahun untuk kain sebanyak 82 roll dan melakukan pembelian ke supplier sebanyak 82 roll, kebutuhan malam sebanyak 119 kilogram dan melakukan pembelian ke supplier sebanyak $125 \mathrm{~kg}$, dan kebutuhan pewarna sebanyak 84 kilogram dan melakukan pembelian ke supplier sebanyak 90 kilogram.

\section{Biaya Persediaan}

Pada UKM Batik "Sekar Jati Star" terdapat dua jenis biaya, yaitu: biaya pemesanan (ordering cost) dan biaya penyimpanan (holding cost).
Tabel 4 Data Biaya Pemesanan

\begin{tabular}{|c|c|c|c|}
\hline No & $\begin{array}{c}\text { Barang Yang } \\
\text { Dipesan }\end{array}$ & Jenis Biaya & Jumlah Biaya \\
\hline \multirow{3}{*}{1} & \multirow{2}{*}{$\begin{array}{l}\text { Pemesanan } \\
\text { kain }\end{array}$} & Biaya telepon & Rp. $3.000,00$ \\
\hline & & Biaya pengiriman & Rp. $280.000,00$ \\
\hline & \multicolumn{2}{|c|}{ Total biaya } & Rp. $283.000,00$ \\
\hline \multirow{3}{*}{2} & \multirow{2}{*}{$\begin{array}{l}\text { Pemesanan } \\
\text { malam }\end{array}$} & Biaya telepon & Rp. 3.000,00 \\
\hline & & Biaya pengiriman & Rp. $210.000,00$ \\
\hline & \multicolumn{2}{|c|}{ Total biaya } & Rp. $213.000,00$ \\
\hline \multirow{3}{*}{3} & \multirow{2}{*}{$\begin{array}{l}\text { Pemesanan } \\
\text { pewarna }\end{array}$} & Biaya telepon & Rp. $3.000,00$ \\
\hline & & Biaya pengiriman & Rp. $140.000,00$ \\
\hline & \multicolumn{2}{|c|}{ Total biaya } & Rp. $143.000,00$ \\
\hline
\end{tabular}

(Sumber: UKM Batik “Sekar Jati Star")

Berdasarkan tabel 3 terdapat dua jenis biaya yang mempengaruhi selama dilakukannya pemesanan yaitu: biaya telepon dan biaya pengiriman.

Tabel 5 Data Biaya Peyimpanan

\begin{tabular}{|c|l|l|l|l|l|l|}
\hline No & $\begin{array}{l}\text { Jenis } \\
\text { Biaya }\end{array}$ & $\begin{array}{l}\text { Jumlah } \\
\text { Biaya } \\
\text { /bulan }\end{array}$ & $\begin{array}{l}\text { Bahan } \\
\text { Baku }\end{array}$ & Ruang & $\begin{array}{l}\text { Jumlah } \\
\text { Biaya } \\
\text { /bulan }\end{array}$ & $\begin{array}{l}\text { Jumlah } \\
\text { Biaya } \\
\text { /tahun }\end{array}$ \\
\hline \multirow{3}{*}{1} & \multirow{2}{*}{$\begin{array}{l}\text { Biaya } \\
\text { Listrik }\end{array}$} & $\begin{array}{l}\mathrm{Rp} \\
100.000\end{array}$ & Kain & $1 / 6$ & $\mathrm{Rp} 16.000$ & $\begin{array}{l}\mathrm{Rp} \\
192.000\end{array}$ \\
\cline { 3 - 7 } & & Malam & $1 / 10$ & $\mathrm{Rp} 10.000$ & $\begin{array}{l}\mathrm{Rp} \\
120.000\end{array}$ \\
\cline { 3 - 7 } & \multicolumn{2}{|l|}{ Pewarna } & $1 / 10$ & $\mathrm{Rp} 10.000$ & $\begin{array}{l}\mathrm{Rp} \\
120.000\end{array}$ \\
\hline
\end{tabular}

Berdasarkan tabel 4 pada UKM Batik "Sekar Jati Star" biaya yang mempengaruhi selama dilakukannya peyimpanan yaitu biaya listrik sebesar Rp 100.000,00. Dimana dalam gudang tersebut kain menempati $1 / 6$ ruang, malam $1 / 10$ ruang, pewarna 1/10 ruang, dan sisanya digunakan untuk penyimpanan bahan baku pendukung dan alat-alat pembuatan batik.

\section{Klasifikasi Menggunakan Metode ABC Analysis}

Metode analisis ABC sangat berguna dalam mengatur terhadap penentuan jenis barang yang paling penting dalam sistem persediaan (Rangkuti, 2004). UKM Batik "Sekar Jati Star" memiliki tiga bahan baku utama dan beberapa bahan baku pendukung. Namun, dalam penelitian ini hanya membahas tiga bahan baku utama yaitu kain, malam, dan pewarna. 


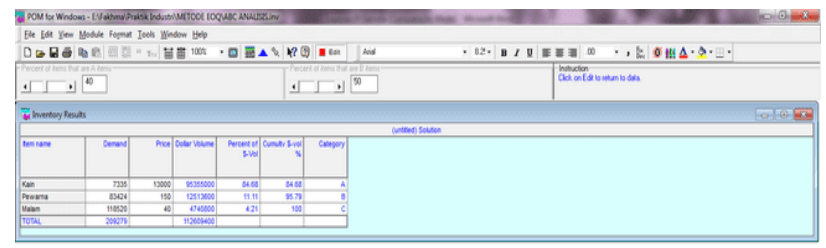

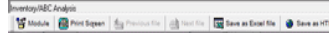

Gambar 1 Hasil Analisis ABC Untuk Bahan Baku

(Sumber: Output POM QM for Windows)

Berdasarkan gambar 1 diketahui bahwa dari 3 item bahan baku, yang termasuk dalam kategori A adalah bahan baku kain. Dimana nilai rupiahnya mencapai 84,68\% setahun (Rp.95.355.000). Yang termasuk kategori B adalah bahan baku pewarna. Dimana nilai rupiahnya mencapai $11,11 \%$ setahun (Rp.12.513.600). Sedangkan yang termasuk kategori $\mathrm{C}$ adalah bahan baku malam dengan nilai rupiahnya mencapai $4,21 \%$ setahun (Rp.4.740.800). Mengacu pada Markland (1983), maka penanganan bahan baku kain yang merupakan kelas A adalah Pengendalian persediaan yang ketat, Sistem pencatatan harus dipantau sehingga tepat. Selanjutnya penanganan bahan baku pewarna merupakan kelas $\mathrm{B}$ dengan pengendalian persediaan sedang, dan penanganan bahan baku malam berada dikelas $\mathrm{C}$ dengan pengendalian persediaan longgar.

\section{Pengendalian Persediaan Metode EOQ}

Pengendalian persediaan dengan menggunakan metode EOQ biasanya digunakan untuk mengetahui jumlah kuantitas pemesanan yang optimal dengan biaya persediaan yang minimum. Pada pengertian EOQ sendiri, EOQ merupakan jumlah barang yang diperoleh dengan biaya minimal atau dengan kata lain pembelian yang optimal.

Perhitungan dalam melakukan EOQ menggunakan software POM QM forwindows untuk menyelesaikan permasalahan di bidang manajemen produksi maupun operasi, dengan perhitungan jumlah kuantitas maupun frekuensi yang optimal.

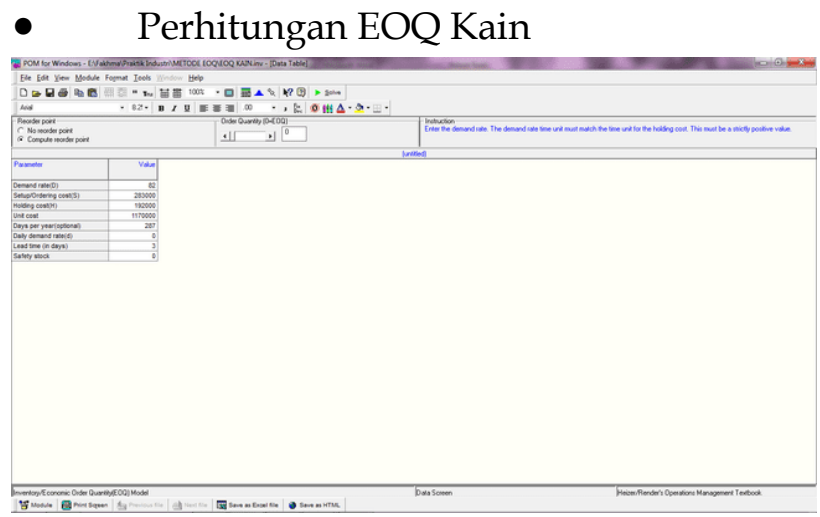

Gambar 2 Parameter EOQ Kain

(Sumber: Output POM QM for Windows)

Pada gambar 2 diketahui bahwa demand untuk kain dalam 1 tahun sebesar 82 roll. Ordering Cost merupakan biaya yang digunakan dalam melakukan pemesanan yaitu pada saat UKM Batik "Sekar Jati Star" melakukan panggilan ke supplier untuk memesan bahan. Holding Cost yang digunakan merupakan biaya penyimpanan yang terdiri dari biaya listrik. Sehingga setelah dilakukan perhitungan untuk bahan baku kain mendapatkan hasil sebagai pada gambar 3 berkut ini.

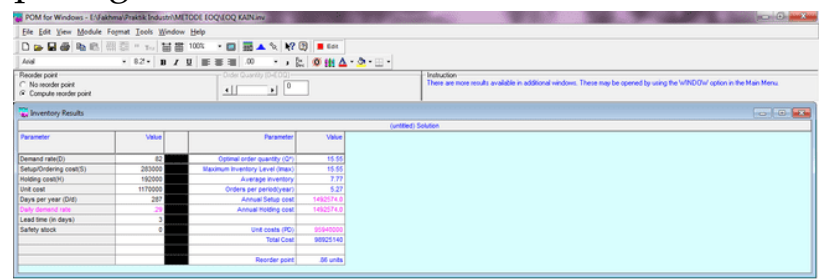

Gambar 3 Perhitungan EOQ Kain

(Sumber: Output POM QM for Windows) Pada gambar 3 diketahui bahwa $\mathrm{Q}^{*}$ optimal sebesar 15,55 roll atau dibulatkan menjadi 16 roll, dengan rata-rata persediaan sebesar 7,77 roll. Frekuensi order per periode sebanyak 5,27 atau sama dengan 5 kali pemesanan dalam 1 tahun. Dengan total biaya pemesanan dan penyimpanan per tahun sebesar Rp 1.492.574. Nilai unit sebesar Rp 95.940.000 maka total cost 
optimal yang dihasilkan untuk bahan baku kain sebesar Rp 98.925.140 dengan reorder point 0,86 roll, yang mana dimaksudkan apabila sudah mencapai titik 0,86 roll atau 77 meter kain maka UKM Batik "Sekar Jati Star" harus sudah melakukan pemesanan kepada supplier. Sedangkan untuk titik equilibrium atau titik keseimbangan untuk kain dapat dilihat pada gambar 4 berikut ini.

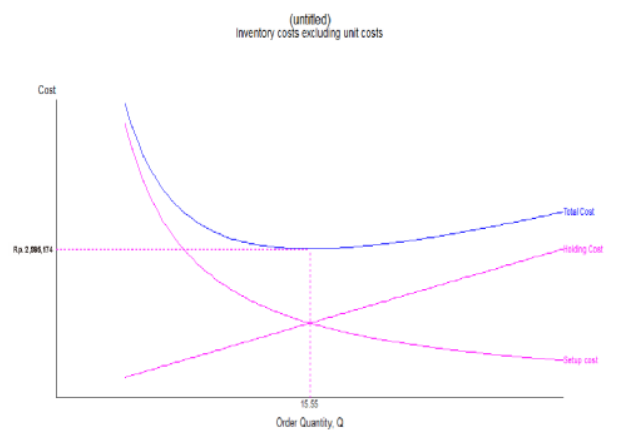

Gambar 4 Hasil Titik Equilibrium Kain (Sumber: Output POM QM for Windows)

Dari gambar 4 diketahui bahwa titik temu antara holdingcost dan setup cost adalah berada di titik 15.55, dimana titik tersebut menunjukkan biaya terendah yang harus dikeluarkan UKM Batik "Sekar Jati Star" untuk bahan baku kain. Sedangkan hasil monitoring EOQ pada bahan baku kain selama 1 tahun diketahui pada gambar 5 berikut ini.

Berdasarkan gambar 5 bahwasanya rata-rata persediaan dalam 1 minggu untuk bahan baku kain adalah sebanyak 7,77 roll. Berdasarkan hasil metode EOQ, diketahui bahwa pemesanan yang paling ekonomis adalah sebesar 15,55 roll untuk tiap kali pesan. Rata-rata titik pemesanan kembali sebesar 0,86 roll. Pemenuhan bahan baku kain terjadi pada minggu ke-1, ke-9, ke-19, dan ke-39. Dimana titik pemesanan kembali untuk pemenuhan bahan baku adalah pada minggu ke-9, ke-19, ke-29, dan minggu ke-39. Total cost per tahun sebesar Rp 98.925.140, yang berasal dari unit cost sebesar Rp 95.940.000, holdingcost sebesar Rp 1.492.574, dan setup cost sebesar Rp 1.492.574.

Apabila dibandingkan dengan fakta, biaya total dari hasil perhitungan EOQ lebih kecil daripada biaya fakta yang dikeluarkan oleh UKM Batik "Sekar Jati Star". Sehingga, hasil perhitungan EOQ ini bisa diterapkan di UKM Batik "Sekar Jati Star".

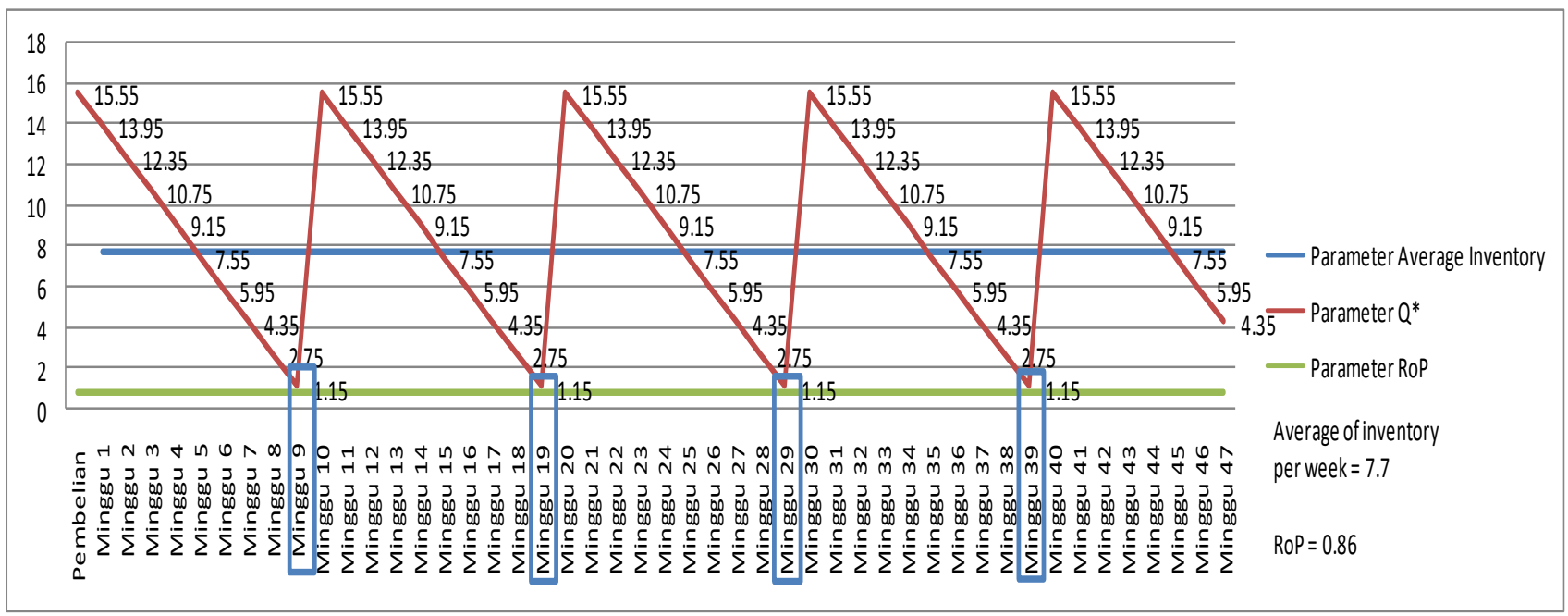

Gambar 5 Monitoring EOQ Bahan Baku Kain Selama 1 Tahun (Sumber: Output Microsoft Excel) 


\section{Perhitungan EOQ Malam}

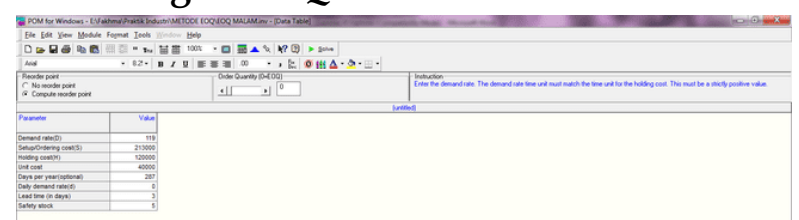

Gambar 6 Parameter EOQ Malam

(Sumber: Output POM QM for Windows)

Pada gambar 6 diketahui bahwa demand untuk malam dalam 1 tahun sebesar 119 kilogram. OrderingCost merupakan biaya yang digunakan dalam melakukan pemesanan yaitu pada saat UKM Batik "Sekar Jati Star" melakukan panggilan ke supplier untuk memesan bahan. HoldingCost yang digunakan merupakan biaya penyimpanan yang terdiri dari biaya listrik.Sehingga setelah dilakukan perhitungan untuk bahan baku malam mendapatkan hasil sebagai pada gambar 6 berkut ini.

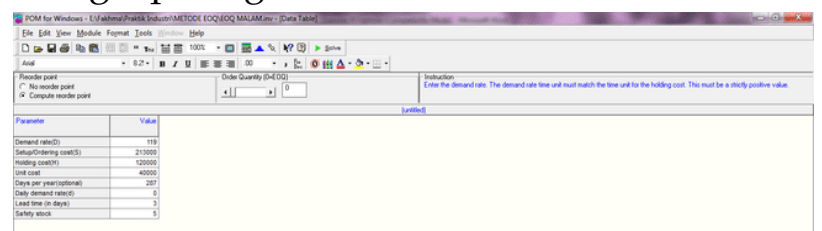

Gambar 7 Perhitungan EOQ Malam

(Sumber: Output POM QM for Windows)

Pada gambar 7 diketahui bahwa $Q^{*}$ optimal sebesar 20,55 kilogram atau dibulatkan menjadi 21 kilogram, dengan rata-rata persediaan sebesar 10,28 kilogram. Frekuensi order per periode sebanyak 5,79 atau sama dengan 6 kali pemesanan dalam 1 tahun. Dengan total biaya pemesanan dan penyimpanan per tahun sebesar Rp 1.233.215. Nilai unit sebesar $\mathrm{Rp}$ 4.760.000 maka total cost optimal yang dihasilkan untuk bahan baku malam sebesar Rp 7.826.431 dengan reorder point 6,24 kilogram, yang mana dimaksudkan apabila sudah mencapai titik 6,24 kilogram malam maka UKM Batik "Sekar Jati Star" harus sudah melakukan pemesanan kepada supplier. Sedangkan untuk titik equilibrium atau titik keseimbangan untuk malam dapat dilihat pada gambar 8 berikut ini.

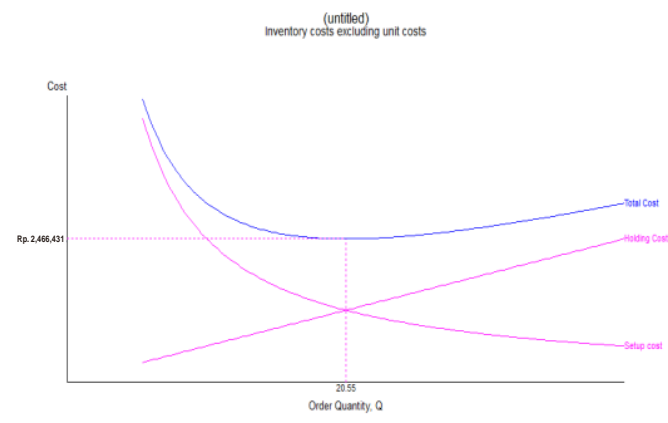

Gambar 8 Hasil titik equilibrium Malam (Sumber: Output POM QM for Windows)

Berdasarkan gambar 8 diketahui bahwa titik temu antara holdingcost dan setup cost adalah berada di titik 20.55, dimana titik tersebut menunjukkan biaya terendah yang harus dikeluarkan UKM Batik "Sekar Jati Star" untuk bahan baku malam. Sedangkan hasil moitoring EOQ pada bahan baku malam selama 1 tahun dapat diketahui pada gambar 9. Berdasarkan gambar 9 bahwasanya rata-rata persediaan dalam 1 minggu untuk bahan baku malam adalah sebanyak 10,28 kilogram. Berdasarkan hasil metode EOQ, diketahui bahwa pemesanan yang paling ekonomis adalah sebesar 20,55 kilogram untuk tiap kali pesan. Rata-rata titik pemesanan kembali sebesar 6,24 kilogram. Pemenuhan bahan baku kain terjadi pada minggu ke-1, ke-8, ke-17, ke-26, ke-35, dan ke-44 Dimana titik pemesanan kembali untuk pemenuhan bahan baku adalah pada minggu ke-8, ke-17, ke-26, ke-35, dan minggu ke-44. Total cost per tahun sebesar Rp 7.826.431, yang berasal dari unit cost sebesar $\operatorname{Rp} 4.760 .000$, holdingcost sebesar Rp 1.233.215, dan setup cost sebesar Rp Rp 1.233.215. Apabila dibandingkan dengan fakta, biaya total dari hasil perhitungan EOQ lebih kecil daripada biaya fakta yang dikeluarkan oleh UKM Batik "Sekar Jati Star". 
Sehingga, hasil perhitungan EOQ ini bisa diterapkan di UKM Batik "Sekar Jati Star".

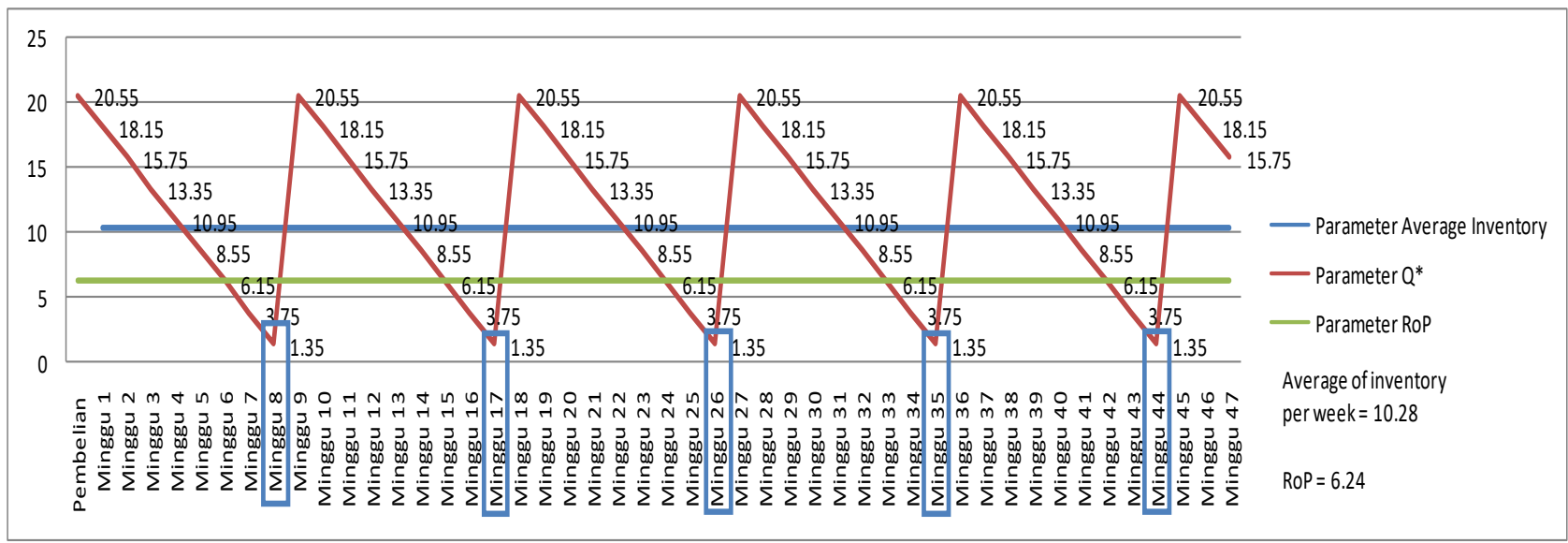

Gambar 9 Monitoring EOQ Bahan Baku Malam Selama 1 Tahun

(Sumber: Output Microsoft Excel)
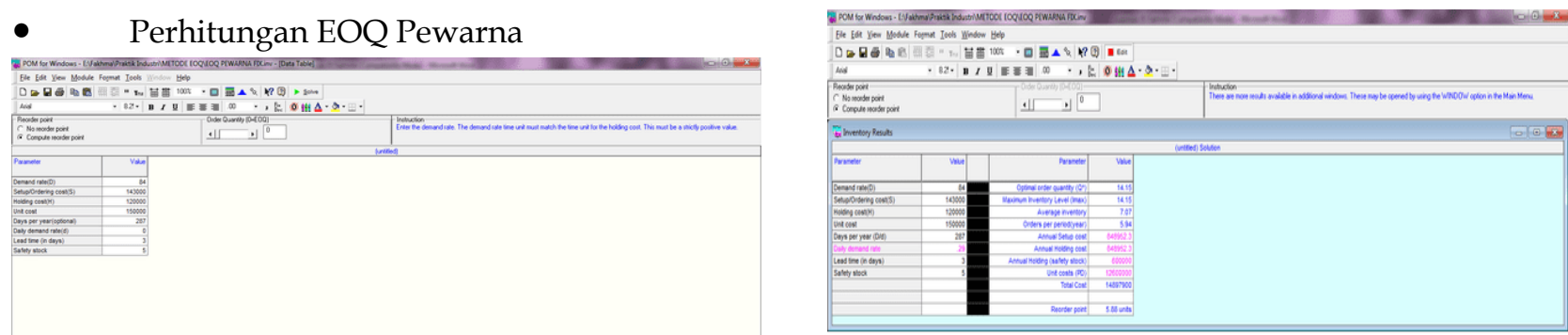

Gambar 10 Parameter EOQ Pewarna

(Sumber: Output POM QM for Windows)

Berdasarkan gambar 10 diketahui bahwa demand untuk pewarna dalam 1 tahun sebesar 84 kilogram. OrderingCost merupakan biaya yang digunakan dalam melakukan pemesanan yaitu pada saat UKM Batik "Sekar Jati Star" melakukan panggilan ke supplier untuk memesan bahan. HoldingCost yang digunakan merupakan biaya penyimpanan yang terdiri dari biaya listrik. Sehingga setelah dilakukan perhitungan untuk bahan baku pewarna mendapatkan hasil seperti pada gambar 11 berkut ini.

Gambar 11 Perhitungan EOQ Pewarna (Sumber: Output POM QM for Windows)

Berdasarkan gambar 11 diketahui bahwa Q* optimal sebesar 14,15 kilogram atau dibulatkan menjadi 14 kilogram, dengan rata-rata persediaan sebesar 7,07 kilogram. Frekuensi order per periode sebanyak 5,94 atau sama dengan 6 kali pemesanan dalam 1 tahun. Dengan total biaya pemesanan dan penyimpanan per tahun sebesar Rp 848.952. Nilai unit sebesar Rp 12.800.000 maka total cost optimal yang dihasilkan untuk bahan baku pewarna sebesar Rp 14.897.900 dengan reorder point 5,88 kilogram, yang mana dimaksudkan apabila sudah mencapai titik 5,88 kilogram pewarna maka UKM Batik "Sekar Jati Star" harus sudah melakukan pemesanan kepada supplier. Sedangkan untuk titik equilibrium atau 
titik keseimbangan untuk pewarnaan dapat dilihat pada gambar 12 berikut ini

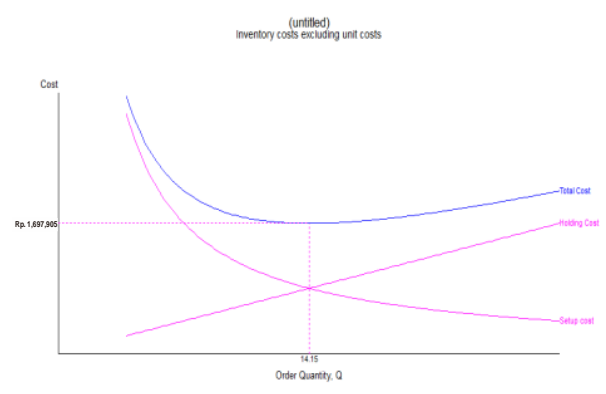

Gambar 12 Hasil titik equilibrium Pewarna

(Sumber: Output POM QM for Windows)

Berdasarkan gambar 12 dapat diketahui bahwa titik temu antara holdingcost dan setupcost adalah berada di titik 14,15, dimana titik tersebut menunjukkan biaya terendah yang harus dikeluarkan UKM Batik "Sekar Jati Star" untuk bahan baku pewarna. Sedangkan hasil moitoring EOQ pada bahan baku pewarnaan selama 1 tahun dapat diketahui pada gambar 13 .
Berdasarkan gambar 13 bahwasanya rata-rata persediaan dalam 1 minggu untuk bahan baku pewarna adalah sebanyak 7,07 kilogram. Berdasarkan hasil metode EOQ, diketahui bahwa pemesanan yang paling ekonomis adalah sebesar 14,15 kilogram untuk tiap kali pesan. Rata-rata titik pemesanan kembali sebesar 5,88 kilogram. Pemenuhan bahan baku kain terjadi pada minggu ke-1, ke-8, ke-17, ke26, ke-35 dan ke-44. Dimana titik pemesanan kembali untuk pemenuhan bahan baku adalah pada minggu ke-8, ke-17, ke-26, ke-35, dan minggu ke-44. Total cost per tahun sebesar Rp 14.897.900, yang berasal dari unit cost sebesar Rp 12.800.000, holdingcost sebesar Rp 848.952, dan setupcost sebesar Rp 848.952.

Apabila dibandingkan dengan fakta, biaya total dari hasil perhitungan EOQ lebih kecil daripada biaya fakta yang dikeluarkan oleh UKM Batik "Sekar Jati Star". Sehingga, hasil perhitungan EOQ ini bisa diterapkan di UKM Batik "Sekar Jati Star".

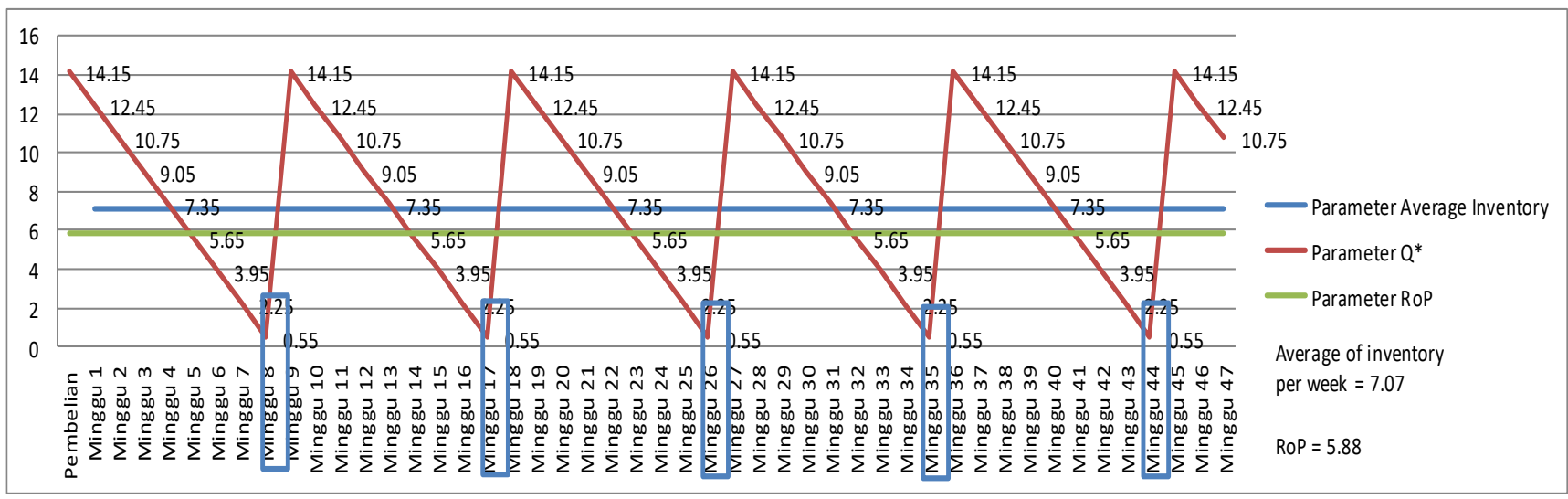

Gambar 4.13 Hasil Monitoring EOQ Bahan Baku Pewarna Selama 1 Tahun (Sumber: Output Microsoft Excel)

\section{PENUTUP}

\section{Simpulan}

Berdasarkan hasil penelitian di UKM Batik "Sekar Jati Star", maka kesimpulan yang diperoleh adalah sebagai berikut.

1. Hasil klasifikasi bahan baku di UKM Batik "Sekar Jati Star" menggunakan ABC Analysis, diketahui bahwa bahan baku yang termasuk dalam kategori A adalah bahan baku kain, yang termasuk kategori B adalah adalah bahan baku pewarna sedangkan yang termasuk kategori $\mathrm{C}$ adalah bahan baku malam.

2. Jumlah pemesanan ekonomis untuk persediaan bahan baku di UKM Batik "Sekar Jati Star" adalah sebagai berikut.

a. Bahan baku kain sebanyak 16 roll atau 1980 meter.

b. Bahan baku malam sebanyak 21 kilogram. 
c. Bahan baku pewarna sebanyak 14 kilogram.

3. Tingkat pemesanan ulang bahan baku di UKM Batik "Sekar Jati Star" yang sesuai kebutuhan adalah sebagai berikut.
a. Bahan baku kain ketika kain sudah mencapai titik 0,86 roll atau 77 meter.
b. Bahan baku malam ketika malam sudah mencapai titik 6,24 kilogram.
c. Bahan baku pewarna ketika pewarna sudah mencapai titik 5,88 kilogram.

4. Pengendalian persediaan bahan baku yang ekonomis di UKM Batik "Sekar Jati Star" dilakukan dengan memonitoring hasil output EOQ dan dibuat rekapitulasi permintaan, pemesanan, dan reorder point dengan grafik.

\section{Saran}

Peneliti berikutnya dapat melakukan penelitian yang berbeda dalam manajemen operasi tidak hanya POM-QM for Windows agar dapat dikembangkan dan mendapat temuan baru.
DAFTAR PUSTAKA

Adistya Yunisty Ambarwati. (2020). Analisis Pengendalian Persediaan Bahan Baku pada Central Kitchen PT XYZ. Laporan Tugas Akhir Teknik Logistik. Jakarta: Fakultas Teknologi Industri Universitas Pertamina.

Amin Widodo., Makhsun Makhsun., Achmad Hindasyah. (2020). Analisis Pengendalian Persediaan Bahan Baku PVC Compound Menggunakan Metode ABC Analisis dan EOQ Berbasis POM-QM forWindows V5.2. Jurnal Informatika. Tangerang Selatan: Universitas Pamulang.

Ardiprawiro. (2015). Dasar Manajemen Keuangan. Jakarta: Universitas Gunadarma.

Fogarty, D., Blackstone, J., \& Hoffmann, T. (1991). ProductionEInventory Management 2 edition. New York.

Frazelle, E. (2001). World Class Warehousing and Material Handling. New York: Mc-GrawHill.

Markland, R. (1983). Topics in Management Science. Hoboken: Wiley.

Purnomo, H. (2004). Perencanaan dan Perancangan Fasilitas. Yogyakarta: Graha Ilmu.

Rangkuti, F. (2004). Riset Pemasaran. Jakarta: PT. Gramedia Pustaka Utama. 